\title{
Inhibition of beta cell growth and function by bone morphogenetic proteins
}

\author{
Christine Bruun • Gitte L. Christensen • Marie L. B. Jacobsen • Marianne B. Kanstrup • \\ Pernille R. Jensen • Helle Fjordvang • Thomas Mandrup-Poulsen • Nils Billestrup
}

Received: 19 June 2014 / Accepted: 2 September 2014 / Published online: 27 September 2014

(C) Springer-Verlag Berlin Heidelberg 2014

\begin{abstract}
Aims/hypothesis Impairment of beta cell mass and function is evident in both type 1 and type 2 diabetes. In healthy physiological conditions pancreatic beta cells adapt to the body's increasing insulin requirements by proliferation and improved function. We hypothesised that during the development of diabetes, there is an increase in the expression of inhibitory factors that prevent the beta cells from adapting to the increased need for insulin. We evaluated the effects of bone morphogenetic protein (BMP) 2 and -4 on beta cells.

Methods The effects of BMP2 and -4 on beta cell proliferation, apoptosis, gene expression and insulin release were studied in isolated islets of Langerhans from rats, mice and humans. The expression of BMPs was analysed by immunocytochemistry and real-time PCR. The role of endogenous
\end{abstract}

C. Bruun · M. L. B. Jacobsen · M. B. Kanstrup · H. Fjordvang •

T. Mandrup-Poulsen $\cdot$ N. Billestrup

Hagedorn Research Institute, Gentofte, Denmark

C. Bruun

Department of Incretin and Islet Biology, Novo Nordisk A/S, Måløv, Denmark

G. L. Christensen • M. L. B. Jacobsen • P. R. Jensen • H. Fjordvang • N. Billestrup $(\bowtie)$

Section for Beta-cell Biology, Department of Biomedical Sciences, University of Copenhagen, Blegdamsvej 3, 2200 Copenhagen N,

Denmark

e-mail: billestrup@sund.ku.dk

T. Mandrup-Poulsen

Core Unit for Medical Research Methodology, Department of Biomedical Sciences, University of Copenhagen, Copenhagen N, Denmark

T. Mandrup-Poulsen

Department of Molecular Medicine and Surgery, Karolinska Institute, Stockholm, Sweden
BMP was investigated using a soluble and neutralising form of the BMP receptor 1A.

Results BMP2 and -4 were found to inhibit basal as well as growth factor-stimulated proliferation of primary beta cells from rats and mice. Bmp 2 and $B m p 4$ mRNA and protein were expressed in islets and regulated by inflammatory cytokines. Neutralisation of endogenous BMP activity resulted in enhanced proliferation of rodent beta cells. The expression of Id mRNAs was induced by BMP4 in rat and human islets. Finally, glucose-induced insulin secretion was significantly impaired in rodent and human islets pre-treated with BMP4, and inhibition of BMP activity resulted in enhanced insulin release.

Conclusions/interpretation These data show that BMP2 and -4 exert inhibitory actions on beta cells in vitro and suggest that BMPs exert regulatory roles of beta cell growth and function.

Keywords Beta cell proliferation - Bone morphogenetic protein $\cdot$ Cell cycle $\cdot$ Glucose-stimulated insulin secretion . Inhibitor of DNA binding

$\begin{array}{ll}\text { Abbreviations } \\ \text { ALK } & \text { Activin-like kinase } \\ \text { BMP } & \text { Bone morphogenetic protein } \\ \text { BMPR } & \text { Bone morphogenetic protein receptor } \\ \text { ECM } & \text { Extracellular matrix } \\ \text { EdU } & \text { 5-Ethynyl-2'-deoxyuridine } \\ \text { GLP-1 } & \text { Glucagon-like peptide 1 } \\ \text { GH } & \text { Growth hormone } \\ \text { HLH } & \text { Helix loop helix } \\ \text { ID } & \text { Inhibitor of DNA binding } \\ \text { PDX1 } & \text { Pancreatic and duodenal homeobox 1 }\end{array}$




\section{Introduction}

Deficiency in functional beta cell mass is a hallmark of both type 1 and type 2 diabetes. Current treatments generally focus on increasing insulin secretion, replacing insulin or improving insulin sensitivity. Although very effective, none of these options are curative. Therefore, a major goal is to identify factors that are capable of restoring beta cell mass and function. In the adult organism, new beta cells can be generated by replication of already existing beta cells, from adult stem/progenitor cells through induction of differentiation or by trans-differentiation of other islet cells [1].

The ability of beta cells to undergo mitosis has been demonstrated in rodents [2-4]. In response to insulin resistance, beta cells proliferate significantly to compensate for the increased demand for insulin $[5,6]$. Several growth factors and pathways, which can induce rodent beta cell proliferation, have been identified [7-11]. In vitro, it has been shown that rodent beta cells can proliferate in response to various growth factors and the effects of these factors seem to be direct and involve classical mitotic signalling and stimulation of entry of cells into the cell cycle [12].

Compared with rodent beta cells, human beta cells appear to have a low replication potential. Human beta cells do retain some capacity to expand in number, since beta cell mass is increased during pregnancy [13] and obesity [14].

In order to improve our understanding of the factors and mechanisms involved in the regulation of beta cell replication and function, it is important to search for novel factors and to study their possible interactions with known beta cell growth inducers. Another strategy is to investigate why beta cells are so resistant to growth factors, which may be linked to the presence of growth inhibitors rather than lack of growth promoters.

The bone morphogenetic proteins (BMPs) belong to the TGF- $\beta$ superfamily of growth and differentiation factors. The two highly identical members BMP2 and -4 interact with the BMP type I receptors, activin-like kinase (ALK)-3 and -6 , which form complexes with the BMP type II receptor and phosphorylate SMAD-1/5/8 mediating the effects of BMP2 and $-4[15]$.

Very little is known about the potential role of BMPs in diabetes. In animal models of both type 1 and type 2 diabetes, BMP2 and -4 mRNA and protein are upregulated in the vasculature [16-19], while no information exists concerning regulated expression of BMPs in islets during the progression of diabetes in humans. However, BMP2 and -4 are expressed in islets [20-22] and BMP2 mRNA is upregulated in response to pro-inflammatory cytokines in human and rodent islets [23, 24]. Whereas important roles for BMP2 and -4 in pancreas and beta cell development are well established [25-27], little information about the effects of these factors on differentiated beta cells exists. Deletion of Bmprla in vivo has indicated that
BMP4 is essential for beta cell function [21, 28], while pharmacological inhibition of BMP activity improves glycaemic control in $d b / d b$ mice [17]. Deletion of a central BMP target gene $I d 1$ also improves glucose metabolism [29], suggesting a complex role of BMPs in glucose homeostasis and islet function.

\section{Methods}

Islet isolation and culture Rat and mouse islets were isolated as described in [30] and [31], respectively. $d b / d b$ and $d b /+$ mice were obtained from Taconic, Lille Skensved, Denmark. Experiments involving animals were approved by the local ethics committee. Human islets were provided through the JDRF Islet Distribution Program. The culture time for islets before stimulation was 5-7 days for rat and human islets and 1 day for mouse islets. Islets were cultured in RPMI1640 medium supplemented with $2 \%$ human serum (Lonza, Basel, Switzerland), or dispersed into single cells using $0.2 \%$ trypsin, $10 \mathrm{mmol} / \mathrm{l}$ EDTA (Gibco BRL, Grand Island, NY, USA) in $1 \times$ Hanks' balanced salt solution (rat) or by digestion with Accutase (human; PAA Laboratories GmbH, Colbe, Germany), as described previously [32].

Dispersed islet cells were plated on coverslips coated with extracellular matrix (ECM; Biological Industries, Kibbutz Beit Haemek, Israel) in medium supplemented with $2 \%$ human serum.

Growth factors and reagents The following reagents were used in this study: BMP2 and BMP4 (R\&D Systems Europe, Oxford, UK); human growth hormone (GH) and liraglutide (Novo Nordisk, Bagsvaerd, Denmark); and recombinant human BMPR-IA/ALK-3/Fc and BMPR-IB/ALK-6/Fc receptor fusion proteins (R\&D Systems).

Proliferation assay Beta cell proliferation was measured in islet cells or intact islets cultured on ECM by $10 \mu \mathrm{mol} / \mathrm{l}$ 5-ethynyl-2'-deoxyuridine (EdU; Invitrogen, Paisley, UK) added $24 \mathrm{~h}$ prior to fixation. Proliferating beta cells were detected by EdU incorporation with Click-iT EdU Cell Proliferation Assay (Invitrogen), followed by staining for insulin or pancreatic and duodenal homeobox 1 (PDX1). A minimum of 1,000 cells were counted per experiment in each condition.

Apoptosis assays Apoptosis was measured in intact islets using the Cell Death Detection Assay (Roche Diagnostics, Basel, Switzerland). Caspase 3/7 activity was measured in islet extracts by the Apo-ONE Caspase3/7 Assay (Promega, Madison, WI, USA).

Western blotting Western blotting was performed as described previously [33]. 
Antibodies and immune staining The following antibodies were used in our experiments: guinea pig anti-insulin, rabbit anti-BMP2, rabbit anti-BMP4 (Abcam, Cambridge, UK); goat anti-BMP2/4 (Neuromics Antibodies, Edina, MN, USA); goat anti-Pdx1 (Beta Cell Biology Consortium, Nashville, TN, USA); rabbit anti-phospho-Smad2, rabbit anti-Smad2/Smad3, rabbit anti-phospho-Smad1/Smad5/Smad8 IgG (Cell Signaling Technology, Danvers, MA, USA); and mouse anti-Smad1 IgG (Santa Cruz Biotechnology, Santa Cruz, CA, USA). Secondary antibodies used for immunocytochemistry were Cy2-, Cy3- or Cy5-conjugated donkey anti-mouse, -rat, -rabbit or -guinea pig (Jackson ImmunoResearch, Suffolk, UK). Rat pancreatic sections were stained using peroxidase (Novared-vector, Vector Labs, Burlingame, CA, USA). Cells and sections were examined using a Zeiss LSM510 confocal microscope (Carl Zeiss, Jena, Germany).

Real-time RT-PCR Total RNA was extracted using the TRIZOL method (Invitrogen). cDNA synthesis was performed by TaqMan Gold RT-PCR kit (Perkin-Elmer, Boston, MA,
USA). TaqMan gene expression probes were obtained from Applied Biosystems (Foster City, CA, USA). Each cDNA sample was subjected to two individual PCR analyses using either probes for the gene of interest or the internal control PPIA.

Insulin release and content Rat and human islets or INS1E cells were pre-incubated with BMP4 or ALK-3/Fc for 4 days before measuring glucose- and forskolin-induced insulin secretion. Insulin release from islets and INS1E cells was determined by static batch incubation or perifusion and insulin was measured as described previously [34]. One hundred islets were used per condition in the perifusion experiments and fractions were collected every $5 \mathrm{~min}$. For static batch incubation, 30 islets were used per condition and insulin release was normalised to DNA content.

Statistical analysis Results are shown as means \pm SEM. Comparisons vs the respective control groups were made by Student's paired $t$ test or ANOVA. A $p$ value of $<0.05$ was considered statistically significant.
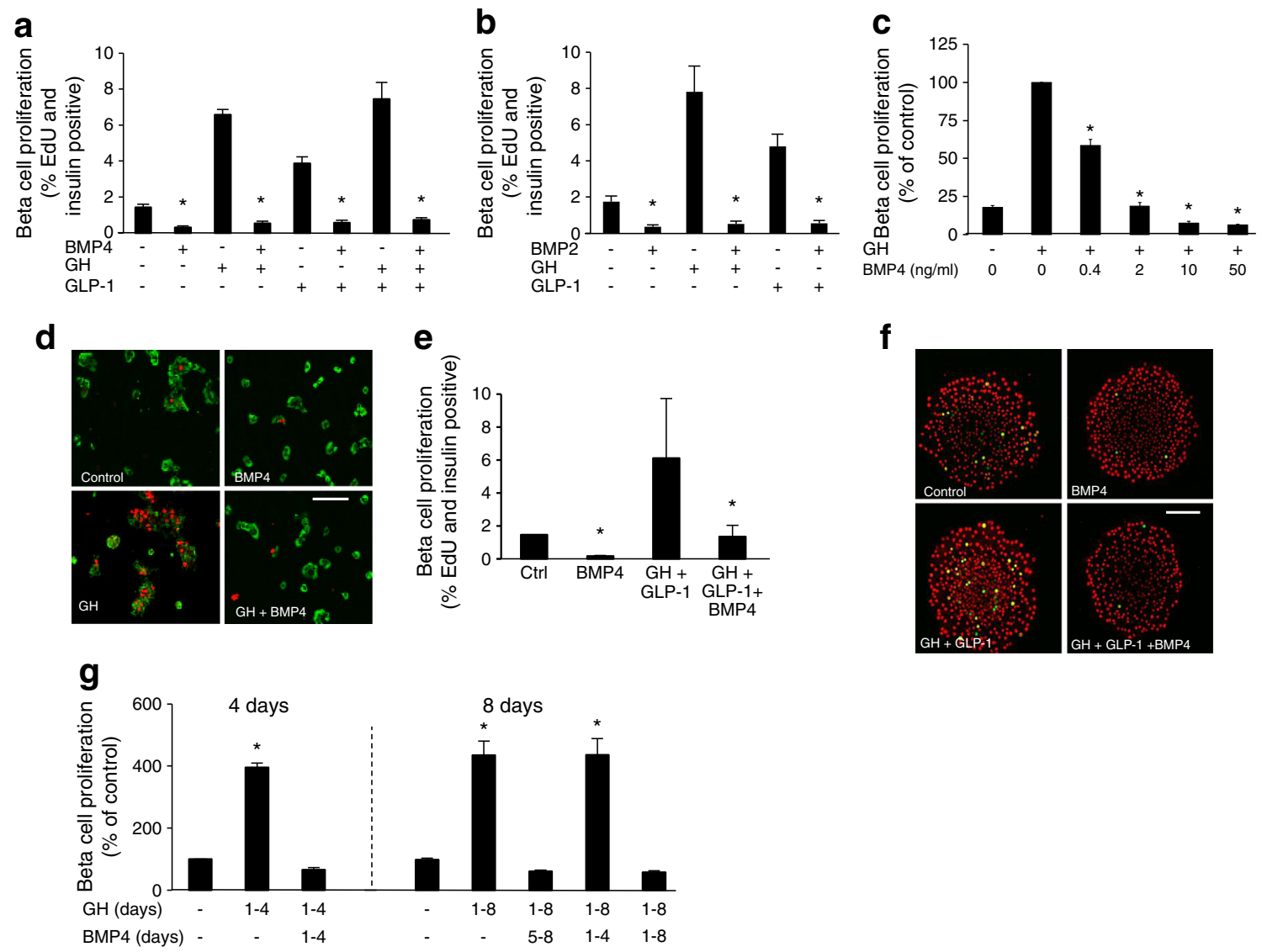

Fig. 1 Regulation of beta cell proliferation by BMP in rat islet monolayer cultures $(\mathbf{a}-\mathbf{d}, \mathbf{g})$ and mouse islets $(\mathbf{e}, \mathbf{f})$. (a-c) Rat islet cells were stimulated for 4 days with BMP4 (a, c) or BMP2 (b) in combination with GH (20 nmol/l) or GLP-1 (40 nmol/l). Proliferation was determined by immunocytochemical staining for insulin and EdU. Results are shown as percentage proliferating beta cells $(n=3)$. (d) Immunocytochemical staining of cultured rat islet cells stained for insulin (green) and EdU (red).

(e) Intact mouse islets stimulated with BMP4 and/or GH (20 nmol/1) + GLP-1 (40 nmol/l), as indicated, for 4 days. Replicating beta cells were identified by EdU and PDX1 co-labelling $(n=4)$. (f) Mouse islets stained for PDX1 (red) and EdU (green). (g) Rat islet cells were stimulated with BMP4 $(50 \mathrm{ng} / \mathrm{ml})$ or $\mathrm{GH}(20 \mathrm{nmol} / \mathrm{l})$ for the indicated experimental days. All results are shown as means \pm SEM. Scale bars, $20 \mu \mathrm{m}$. ${ }^{*} p<0.05$ vs control 


\section{Results}

Regulation of beta cell proliferation by BMP4 The ability of BMP4 to regulate beta cell proliferation was studied in cultures of rat and mouse islet cells. Under basal conditions 1.4\% of beta cells incorporated EdU during a $24 \mathrm{~h}$ labelling period. Stimulation with BMP4 for 4 days resulted in a significant reduction of beta cell proliferation with only $0.3 \%$ of beta cells showing EdU incorporation (Fig. 1a). The inhibitory effect of BMP4 was also evident when proliferation was stimulated with beta cell growth factors (Fig. 1a). Similar effects were observed using BMP2, which is highly homologous to BMP4 (Fig. 1b). BMP4 inhibited proliferation of GH-stimulated beta cells in a dose-dependent manner with significant inhibition observed at $0.4 \mathrm{ng} / \mathrm{ml} \mathrm{BMP} 4$ and maximal inhibition observed at $10 \mathrm{ng} / \mathrm{ml}$ (Fig. 1c, d). In order to study the effect of BMP4 on adult beta cell proliferation, we cultured intact adult mouse islets in the presence of BMP4 alone or in combination with GH and glucagon-like peptide 1 (GLP-1) for 4 days. In control conditions, $1.5 \%$ of PDX-1 positive cells had incorporated EdU, which was significantly inhibited by BMP4 (Fig. 1e, f). To test whether the growth inhibitory effect of BMP4 was reversible, rat islet cells were stimulated with BMP4 for 4 days and subsequently cultured for an additional 4 days in the absence of BMP4. The proliferation of beta cells during the last $24 \mathrm{~h}$ in these cultures was similar to that seen without exposure to BMP4 (Fig. 1g), indicating that the effect of BMP4 was reversible. To test whether inhibition of proliferation by BMP4 was associated with induction of apoptosis, we analysed islet apoptosis in response to BMP4. BMP4 did not induce apoptosis (Fig. 2a, b) whereas IL-1 $\beta$, a known inducer of beta cell apoptosis, showed significant induction of apoptosis and caspase $3 / 7$ activity.

BMP signalling in beta cells We analysed the phosphorylation of SMAD1/5/8 in response to BMP4 by western blotting. Basal SMAD1/5/8 phosphorylation could be detected in both rat and human islets. BMP4 stimulation significantly increased phosphorylation of SMAD1/5/8, whereas BMP4 did
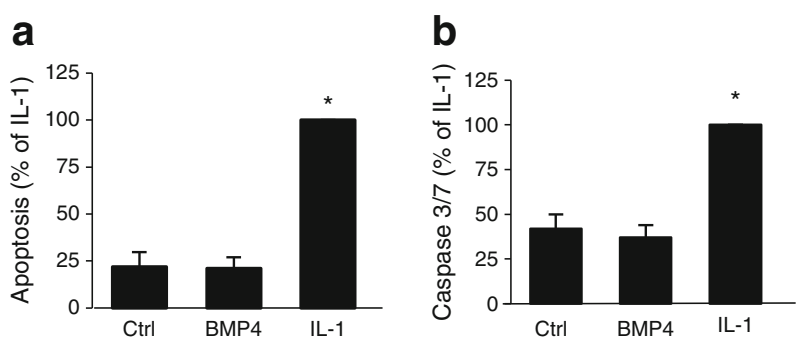

Fig. 2 Effects of BMP4 on beta cell apoptosis. Rat islets were stimulated for $48 \mathrm{~h}$ with BMP4 $(50 \mathrm{ng} / \mathrm{ml})$ or IL-1 $\beta(150 \mathrm{pg} / \mathrm{ml})$. (a) Apoptosis and (b) activation of caspase $3 / 7$ activity was measured in islet lysates. Data are expressed as percentage of maximal apoptosis/caspase activity in the presence of the positive control IL- $1 \beta$ and are shown as means + SEM $(n=3) . * p<0.05$ vs control not affect the phosphorylation of SMAD2/3 (Fig. 3a-c). Similarly, activin A which normally signals via SMAD2/3 induced phosphorylation of SMAD2/3 but not SMAD1/5/8. To test whether the observed phosphorylation of SMAD1/5/8 after BMP4 stimulation was due to activation in beta cells, we performed double immunocytochemical staining for p-SMAD1/5/8 and insulin. Figure $3 \mathrm{~d}$ shows induction of nuclear p-SMAD1/5/8 immune-reactivity in beta cells after stimulation by BMP4.

Expression and effects of islet-derived BMP2 and -4 Expression of Bmp 2/4 mRNA in islets has previously been reported, suggesting a possible auto- or paracrine effect of BMPs on beta cells. We examined the expression of BMP2 and -4 proteins by immunohistochemical staining of rat pancreas and cultured islet cells. We were unable to identify antibodies for specific identification by immunohistochemistry of BMP2 and BMP4 in paraffin-embedded tissue. Using an antibody that recognises both BMP2 and BMP4, we observed specific staining in both islet and exocrine tissue (Fig. 4a). In cultured
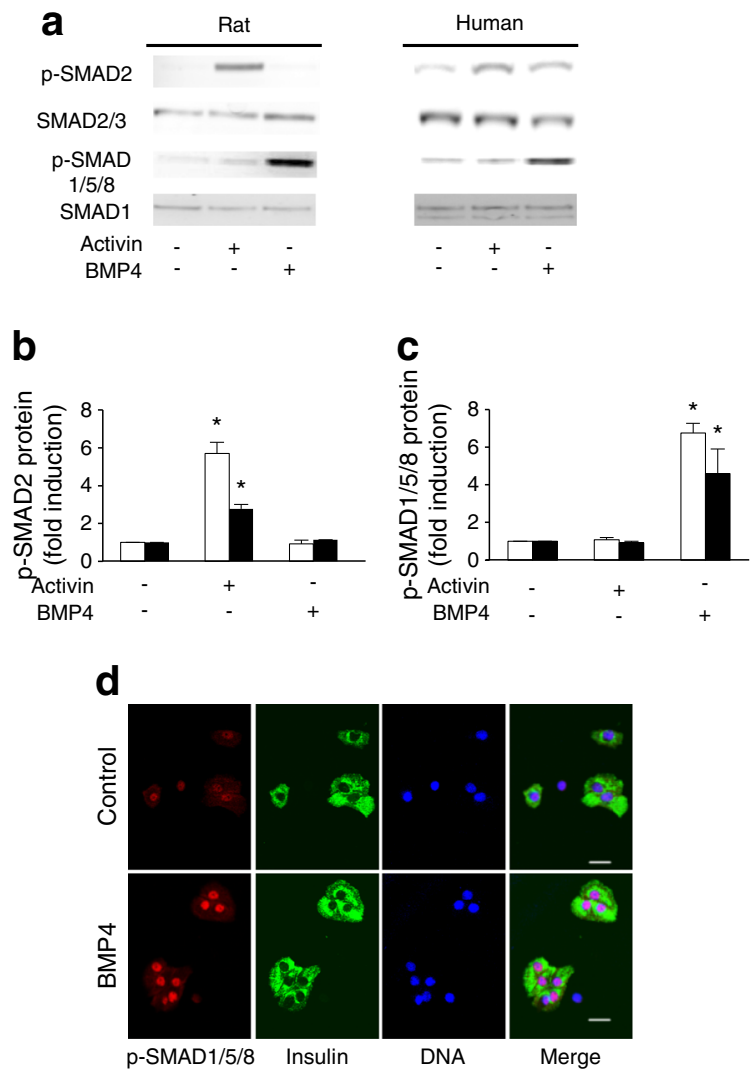

Fig. 3 Phosphorylation of SMAD proteins by BMP4 in islets. (a) Rat or human islets were stimulated with BMP4 $(50 \mathrm{ng} / \mathrm{ml})$ or activin A $(50 \mathrm{ng} / \mathrm{ml})$ for $30 \mathrm{~min}$, as indicated. Cell lysates were subjected to western blotting. Results from 1 of 3 independent experiments are shown. (b) Quantifications of p-SMAD2 and (c) p-SMAD1/5/8. Data are expressed as means $+\operatorname{SEM}(n=3)$. White bar, rat islets; black bar, human islets. (d) Rat islet single cells were stimulated for $30 \mathrm{~min}$ and stained for insulin (green), DNA (blue) and p-SMAD1/5/8 (red). Scale bar, $20 \mu \mathrm{m}$ 
rat and human islet cells it was possible to obtain specific staining for BMP2 and -4. BMP2 and BMP4 expression was observed in cultures of rat and human islets (Fig. 4b, c). BMP2 and -4 immunoreactivity was observed in beta cells as well as in non-beta cells. Also, Bmp2 and - 4 mRNA could be detected in islets (see below) indicating that BMP2 and -4 are expressed and produced in islets.

Since BMP2 and -4 are produced in islets, we examined the possible auto- or paracrine effects by using ALK-3 and
ALK-6/Fc fusion proteins. These fusion proteins consist of the extracellular domain of BMPR1 a and b, respectively, fused to $\mathrm{Fc}$ and are able to neutralise BMP activity through the binding of BMP2 and -4 with high affinity. ALK-3/Fc and ALK-6/Fc fusion proteins were able to neutralise the effect of exogenous BMP4 on beta cell proliferation in a specific manner (Fig. 4d). When islet cell cultures were incubated with ALK-3/Fc or ALK-6/Fc for 4 days, significant stimulation of basal as well as GH-stimulated beta cell proliferation was observed (Fig. 4e)
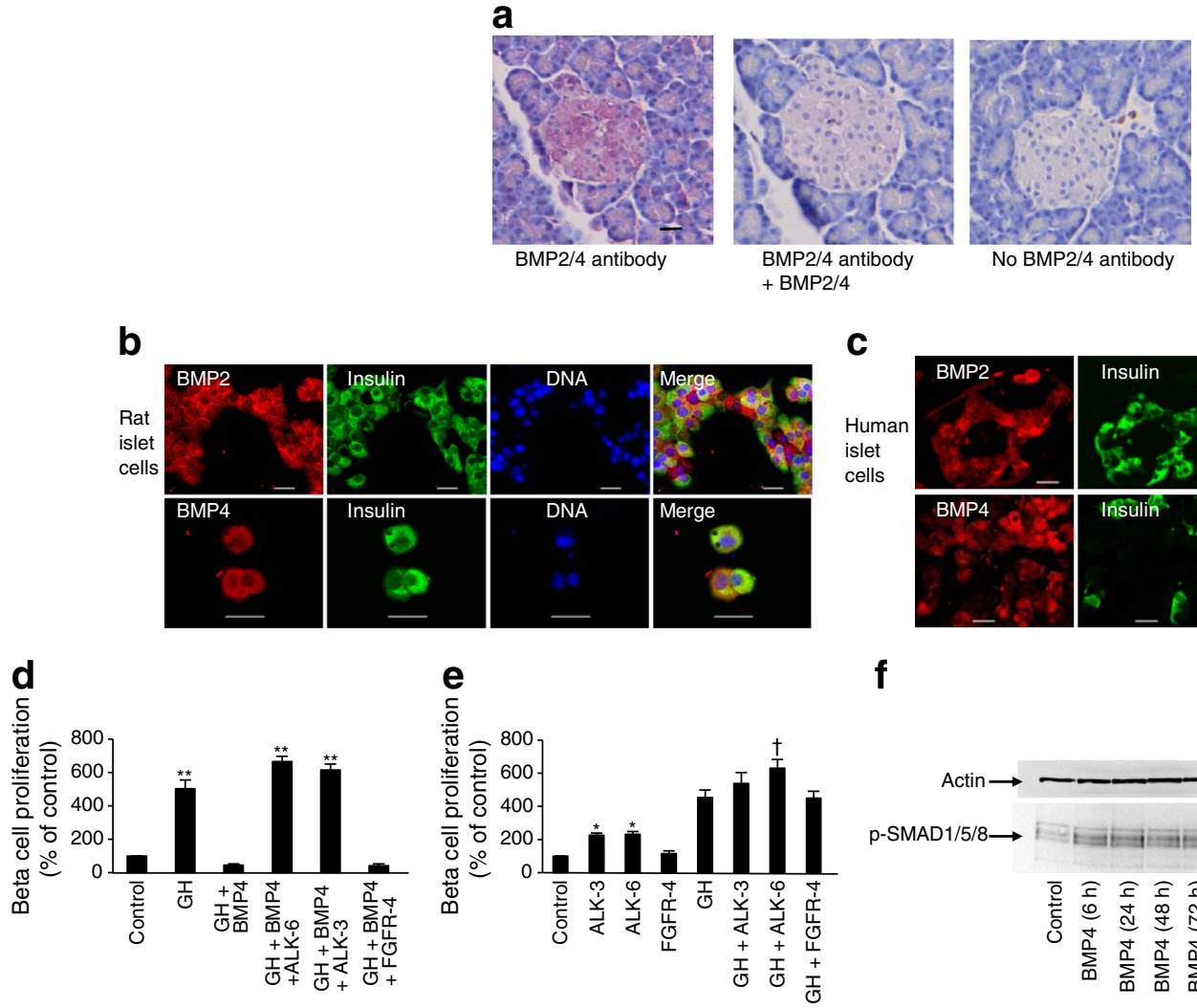

f

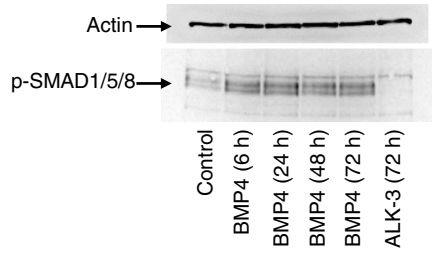

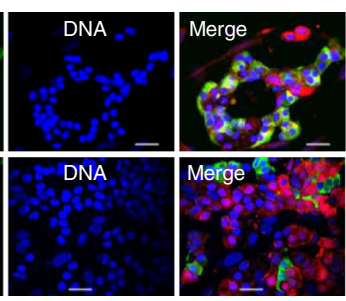

g

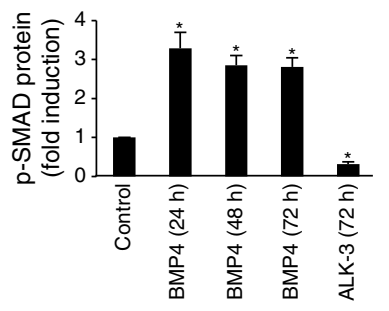

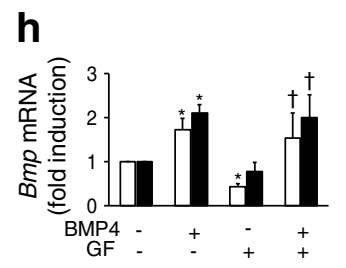
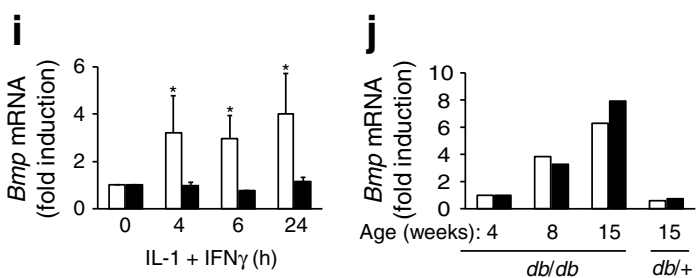

Fig. 4 Rat, mouse and human islet cells express and respond to BMP2 and BMP4. (a) Sections of rat pancreas were stained for BMP2/4. Antibody specificity was tested by pre-incubation with BMP2 and BMP4 or with secondary antibodies only. (b) Rat and (c) human islet single cells were cultured and stained for insulin (green), DNA (blue), BMP2 (red) and BMP4 (red). Scale bars, $20 \mu \mathrm{m}$. (d, e) Rat beta cell proliferation in response to $\mathrm{GH}(20 \mathrm{nmol} / \mathrm{l}), \mathrm{BMP} 4(50 \mathrm{ng} / \mathrm{ml}), \mathrm{BMPR} 1 \mathrm{~A}$ (ALK-3 $[10 \mu \mathrm{g} / \mathrm{ml}]$ ), BMPR1B (ALK-6 [50 $\mu \mathrm{g} / \mathrm{ml}]$ ) or FGFR-4 $(50 \mu \mathrm{g} / \mathrm{ml})$ alone or in combination as indicated $(n=3) .{ }^{*} p<0.05$ vs control ${ }^{*} p<0.01$ and ${ }^{\dagger} p<0.05$ vs GH. (f) Rat islets were stimulated with BMP4 or ALK-3/Fc as indicated and p-SMAD1/5/8 was analysed by western blotting. (g) Quantification of p-SMAD1/5/8 $(n=3) .{ }^{*} p<0.05$ compared with control. (h) Rat islets were stimulated with a mixture of growth factors (GF: GH [20 nmol/1], GLP-1 [40 nmol/1] and activin [50 ng/ml] $)$ and/or BMP4 $(50 \mathrm{ng} / \mathrm{ml})$ for $72 \mathrm{~h}$ or (i) stimulated with a combination of IL-1 $\beta(150 \mathrm{pg} / \mathrm{ml})$ and IFN- $\gamma(1 \mathrm{ng} / \mathrm{ml})$ for the indicated times. Total RNA was isolated and Bmp2 (white bars) and Bmp4 (black bars) mRNA expression was analysed using real-time PCR. Expression levels were normalised to controls $(n=3)$. ${ }^{*} p<0.05$ vs control and ${ }^{\dagger} p<0.05$ vs GF-stimulated islets. (j) Islets were isolated from groups of five $d b / d b$ or $d b /+$ mice at the indicated age and total RNA was isolated. Bmp2 (white bars) and Bmp4 (black bars) mRNA was analysed by realtime RT-PCR and normalised to an internal control. Results are shown as mean for two independent experiments. Data are shown as means \pm SEM. FGFR4, fibroblast growth factor receptor subunit 4; GF, growth factor 
indicating an inhibitory activity of endogenous BMP. In addition, we found that ALK- $3 / \mathrm{Fc}$ treatment of rat islets for 4 days inhibited the basal level of SMAD1/5/8 phosphorylation by $71 \%$, whereas prolonged exposure to BMP4 resulted in a sustained activation of SMAD1/5/8 (Fig. 4f, g).

Since BMP 2 and -4 are produced by islets and exert growth inhibitory actions, we next examined the regulation of Bmp2 and -4 mRNA expression. The combination of beta cell growth factors (GH, GLP-1 and activin) reduced the expression of Bmp2 but not Bmp4 mRNA, while exogenous BMP4 increased the expression of both $B m p 2$ and -4 mRNAs (Fig. 4h). The pro-inflammatory cytokines IL- $1 \beta$ and IFN- $\gamma$, known to impair beta cell growth and function, induced the expression of Bmp 2 mRNA, while Bmp 4 mRNA expression was not affected (Fig. 4i). Finally, we investigated the expression of Bmp2 and -4 mRNAs in islets isolated from diabetic $d b / d b$ mice. Both Bmp2 and Bmp 4 mRNA expression increased with age and progression of diabetes and was 6-7 times higher in islets from 15 -week-old $d b / d b$ mice compared with 4-week-old mice (Fig. 4j). In contrast, Bmp2 and -4 mRNA expression in islets from 15 -week-old $d b /+$ mice was lower than that observed in 4-week-old $d b / d b$ mice and less than $10 \%$ of that seen in age-matched $d b / d b$ mice.

Regulation of islet gene expression by BMP4 The family of $I d$ genes, Idl to 4, are known downstream targets of BMPR activation [35]. Their expression in primary rat and human islets was analysed by real-time RT-PCR. In rat islets both BMP4 and BMP2 induced significant increases in $I d 1,-2,-3$ and -4 mRNA expression (Fig. 5a). In human islets, BMP4 induced a rapid and sustained increase (2-5 fold) in the expression of ID1, ID2, ID3 and ID4 mRNA (Fig. 5b).

We examined the expression of $p 15^{\operatorname{Ink} 4 b}, p 16^{\operatorname{Ink} 4 a}, p 18^{\operatorname{Ink} 4 c}$, $p 19^{I n k 4 d}, p 21^{C i p}, p 27^{K i p 1}$ and $p 57^{K i p 2}$ in rat islets in response to stimulation with BMP4 and/or the combination of GH, GLP-1 and activin. Stimulation of islet cells with growth factors led to a significant decrease in the expression levels of $p 15, p 16, p 21$ and $p 57$ mRNA, which was reversed by BMP4 (Fig. 5c).

The beta cell transcription factor paired box gene 4 (PAX4) has previously been found to induce beta cell proliferation [36] and the expression of Pax4 mRNA was significantly reduced by $50 \%$ in islets after 4 days exposure to BMP4, suggesting that the reduced expression of this transcription factor might contribute to the growth inhibitory actions of BMP4 (Fig. 5d).

Inhibition of glucose- and forskolin-induced insulin secretion by BMP4 After 4 days of incubation with BMP4 or the BMP neutralising ALK-3/Fc fusion protein, insulin release in response to $15 \mathrm{mmol} / \mathrm{l}$ glucose and $15 \mathrm{mmol} / \mathrm{l}$ glucose plus forskolin was measured by perifusion of rat or human islets (Fig. 6a, e). In rat islets (Fig. 6a), BMP4 pre-treatment significantly inhibited glucose- and forskolin-stimulated insulin

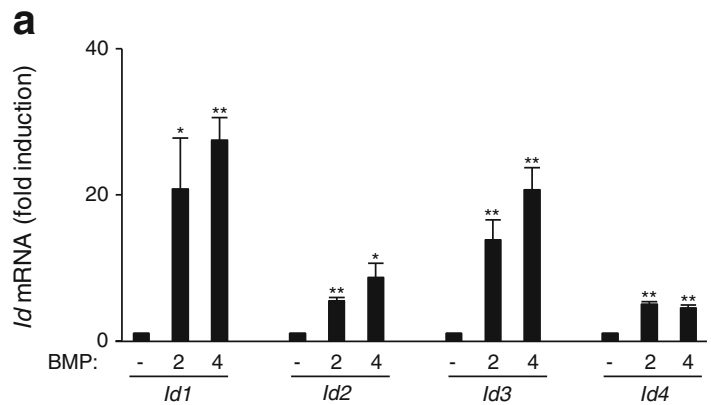

b

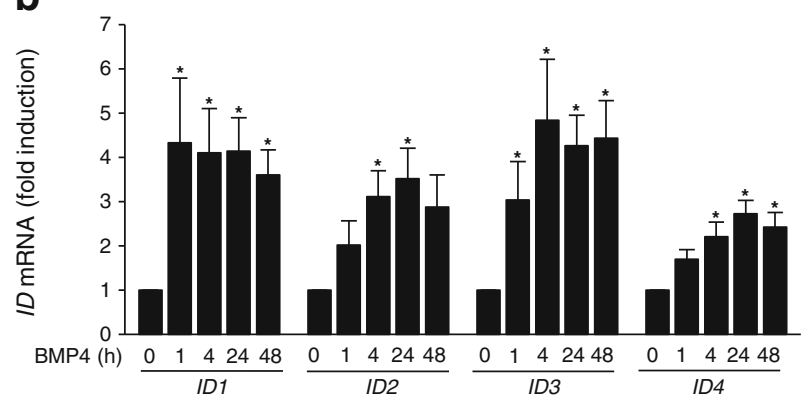

C
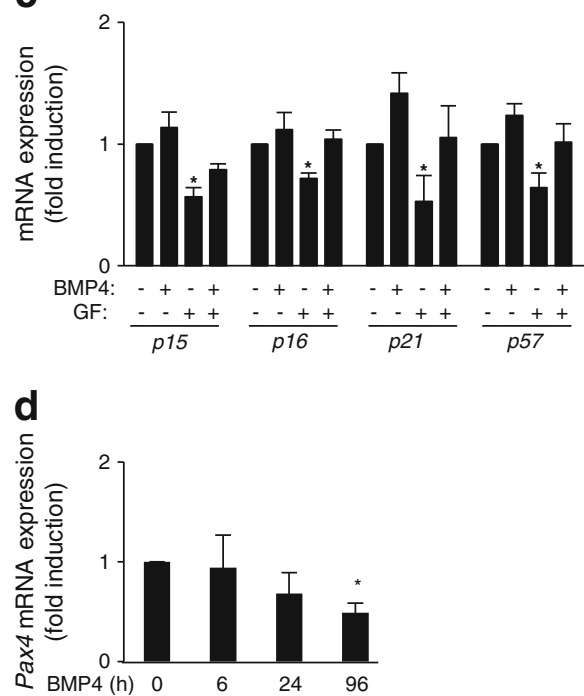

Fig. 5 Effects of BMP2 and BMP4 on gene expression in islets. (a) Rat islet cells were stimulated with $50 \mathrm{ng} / \mathrm{ml} \mathrm{BMP} 2$ or BMP4 for $72 \mathrm{~h}$, as indicated or (b) human islet cells were stimulated with $50 \mathrm{ng} / \mathrm{ml} \mathrm{BMP} 4$ or (c) rat islets were stimulated with $50 \mathrm{ng} / \mathrm{ml} \mathrm{BMP4}$ in combination with growth factors (GF: GH [20 nmol/1], GLP-1 [40 nmol/1] and activin [50 ng/ml]) as indicated, for $72 \mathrm{~h}$, and total RNA was extracted. (a) Id1-4, (b) ID1-4, (c) p15, p16, p21 and p57 and (d) Pax 4 mRNAs were analysed using real-time PCR. Expression levels are normalised to controls and are shown as means $+\operatorname{SEM}(n=3-5) .{ }^{*} p<0.05, * * p<0.01$ vs control. GF, growth factors

secretion, while pre-treatment with ALK-3/Fc enhanced forskolin-induced insulin secretion (Fig. 6b-d). In human islets, pre-treatment with BMP4 inhibited forskolin-induced insulin secretion while ALK-3/Fc pre-treatment enhanced forskolin-induced insulin secretion (Fig. 6f, g). Islet insulin 

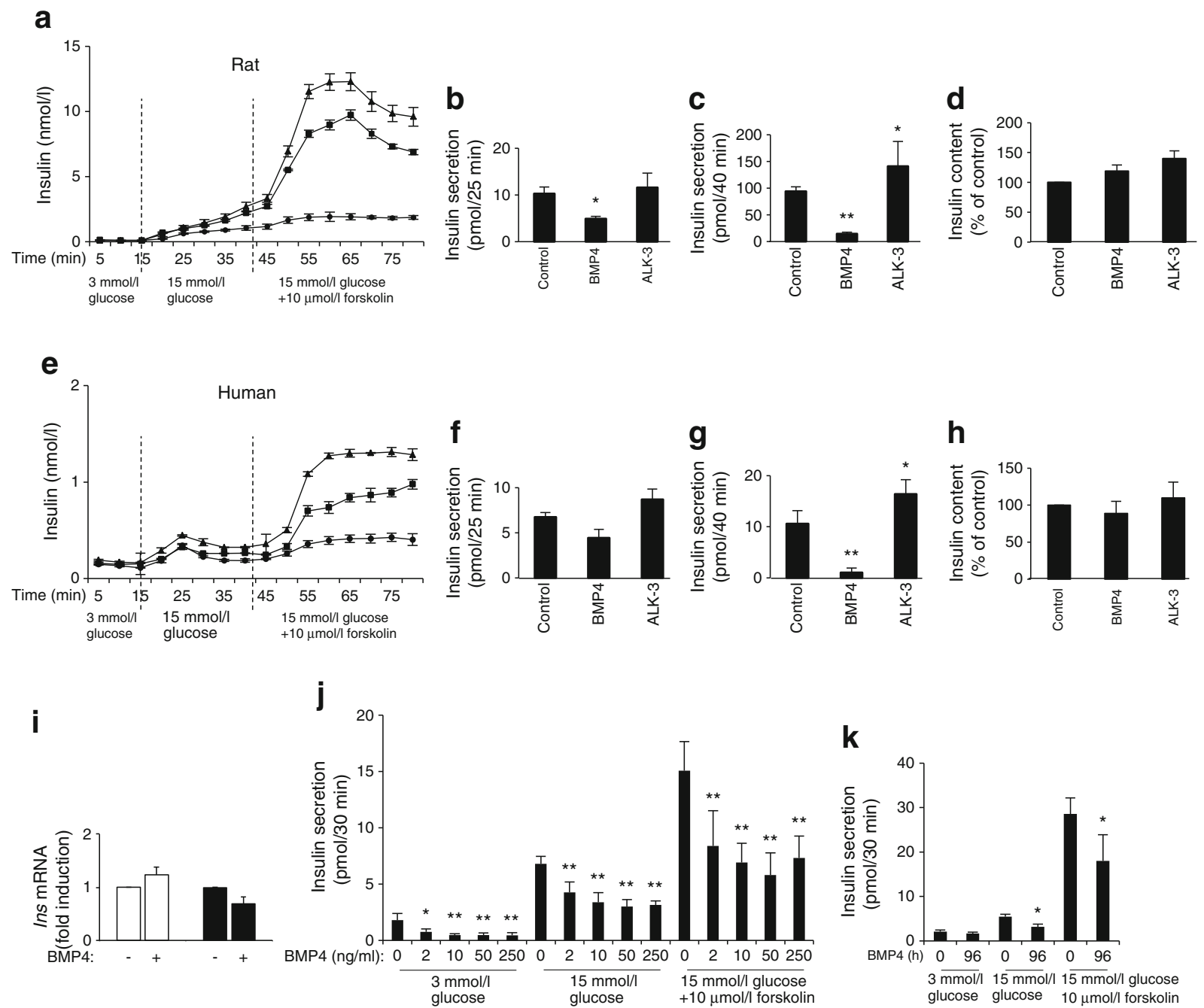

Fig. 6 Effect of BMP4 and ALK-3/Fc on glucose- and forskolin-induced insulin release in islet perifusion. (a-d) Rat or (e-h) human islets were stimulated for 4 days in control medium (black squares), with $50 \mathrm{ng} / \mathrm{ml}$ BMP4 (black circles) or with $10 \mu \mathrm{g} / \mathrm{ml}$ ALK-3/Fc fusion protein (black triangles). The accumulated insulin release in response to $15 \mathrm{mmol} / \mathrm{l}$ glucose $(\mathbf{b}, \mathbf{f})$ or $15 \mathrm{mmol} / \mathrm{l}$ glucose $+10 \mu \mathrm{mol} / \mathrm{l}$ forskolin $(\mathbf{c}, \mathbf{g})$ was calculated for rat $(\mathbf{b}, \mathbf{c})$ and human $(\mathbf{f}, \mathbf{g})$ islet perifusion experiments. Data are shown as means + SEM for 6-8 perifusions. Islet insulin content of (d) rat and (h) human islets was measured after stimulation with BMP4 or
ALK-3/Fc for 4 days. Results are shown as means $+\operatorname{SEM}(n=3)$. (i) Expression of Ins 1 and Ins 2 mRNAs was analysed by real-time PCR from rat islets stimulated for 4 days with or without $50 \mathrm{ng} / \mathrm{ml} \mathrm{BMP} 4$. Results are shown as means + SEM $(n=3)$. ( $\mathbf{j}, \mathbf{k})$ Glucose- and forskolininduced insulin secretion in rat islets $(\mathbf{j})$ and INS1E cells $(\mathbf{k})$ pre-treated with BMP4 for $96 \mathrm{~h}$ measured by static batch incubations and normalised for DNA content. Data are shown as means + SEM. ${ }^{*} p<0.05$ and $* * p<0.01$ vs control content was not affected by BMP4 or ALK-3/Fc treatment (Fig. 6d, h) nor did BMP4 affect the level of Ins1 or Ins 2 mRNAs (Fig. 5i). A significant reduction of insulin release at $3 \mathrm{mmol} / \mathrm{l}$ glucose was observed at $10 \mathrm{ng} / \mathrm{ml}$ and higher concentrations of BMP4, whereas inhibition by $2 \mathrm{ng} / \mathrm{ml}$ and higher concentrations of BMP4 was evident at $15 \mathrm{mmol} / \mathrm{l}$ glucose (Fig. 6j). To test whether the inhibitory activity of BMP4 on insulin release might be dependent on other cell types present in islets, we studied the effect of BMP4 on insulin release from the clonal beta cell line INS1E. BMP4 inhibited both glucose- and forskolin-induced insulin release from INS1E cells after exposure to BMP4 (Fig. 6k).

\section{Discussion}

The relatively scarce number of studies addressing the effects of BMP2 and -4 on regulation of postnatal beta cell mass and function stands in contrast to the extensive knowledge that exists of the critical functions that these growth factors have in the embryonic development of the pancreas [20, 37]. Expression of BMP2 and -4 is observed in postnatal mature islets [21-24]. In particular, BMP2 mRNA appears to be upregulated in islets from both rodents and humans by the proinflammatory cytokines IL- $1 \beta$ and IFN- $\gamma$, which are known to decrease beta cell function and survival [23, 24]. Effects of 
BMP2 and -4 on mature beta cell function have been addressed in few studies [17, 21, 28, 38] and to our knowledge only one study has addressed the in vitro effects showing no effect on insulin secretion after $24 \mathrm{~h}$ exposure to BMP4 [38]. We show that $B m p 2$ expression is increased by inflammatory cytokines in islets, supporting previous mRNA array studies $[23,24]$ and that both Bmp2 and -4 mRNAs were already increased in islets at 4 weeks of age before the onset of diabetes in $d b / d b$ mice. These observations are in accordance with others showing increased vascular expression of BMP2 and/or -4 in diabetic mice [16-19].

We found that BMP4 inhibits beta cell proliferation and insulin secretion. The latter observation is in contrast with that found in mice with beta cell specific deletion of Bmpr1a [21]. These mice have a normal number of beta cells but altered islet alpha and beta cell distribution, and impaired glucosestimulated insulin secretion and glucose tolerance. In addition, BMP4 stimulation in vivo resulted in enhanced insulin secretion in response to glucose as well as improved glucose tolerance [21]. This was associated with a stimulatory effect of BMP4 on several beta cell genes, including the Ins gene, an effect that we do not observe after in vitro stimulation of islets with BMP4. A possible explanation for the discrepancy between our in vitro findings and those reported from genetically manipulated mice could be that the mice may have perturbed BMP signalling during embryonic development from the time of Ins or $P d x 1$ expression affecting the correct developmental programme for regulated insulin secretion. The presence of alpha cells scattered throughout the islets could indicate developmental effects of perturbed BMP signalling. Alternatively, we cannot exclude the possibility that some of the in vivo observations are the results of inter-organ interactions, which are not present in our islet cultures.

Surprisingly, no effect was reported on the expression of Id1 mRNA in islets from mice with either inhibition or stimulation of BMP signalling [21]. In our studies BMP4 stimulates the expression of all four $I d$ genes in cultured rat and human islet cells. Deletion of $I d I$ in mice was associated with enhanced beta cell function indicating that inhibitor of DNA binding 1 (ID1) is a negative regulator of insulin secretion [29]. The ID proteins are dominant negative members of the helix loop helix (HLH) family of transcription factors [39] and ID2 was able to bind and inhibit the basic HLH transcription factor NeuroD. Deletion of the NeuroD gene in beta cells results in islets with a poor response to glucose and a phenotype resembling immature beta cells [40]. BMP4-induced expression of ID proteins and subsequent inhibition of $\mathrm{HLH}$ transcription factors required for beta cell function might explain our observation of diminished insulin secretion in BMP4-treated islets.

Recently published studies demonstrate a positive correlation between local tissue-specific upregulation of BMP2 and/ or -4 expression and diabetes-mediated diseases including retinopathy [41] and nephropathy [42], and vascular defects including atherosclerosis, calcification and hypertension [16, 19, 43]. Moreover, inhibition of BMP was demonstrated to have beneficial effects on these variables [16, 17, 42, 43]. A study with diabetic $d b / d b$ mice further revealed that BMP inhibition not only reduced vascular inflammation but also significantly lowered blood glucose levels [17].

In summary, our findings suggest that BMP2 and -4 negatively regulate beta cell proliferation and function. Alleviation of para- and autocrine effects of BMP 2 and -4 by BMP neutralising agents such as ALK-3/Fc may represent a novel approach for protection and regeneration of adequate functional beta cell mass in diabetes.

Acknowledgements We thank J. Tybjerg, L. G. Petersen (University of Copenhagen) and T. M. Olsen (Novo Nordisk A/S) for expert technical assistance. Human islets were provided through the Juvenile Diabetes Research Foundation Islet Distribution Program (JDRF award 6-20051178) by Islet Cell Resource Centres in Milan (Italy) and Lille (France).

Funding The work was supported by grants from the Danish Council for Independent Research/Medical Sciences, Gerda and Aage Hensch Foundation, The A.P. Møller Foundation for the Advancement of Medical Science, The European Foundation for the Study of Diabetes, The Danish Diabetes Academy and the Novo Nordisk Foundation.

Duality of interest The authors declare that there is no duality of interest associated with this manuscript.

Contribution statement $\mathrm{CB}$ and NB designed the study, performed experiments, analysed data and wrote the first draft of the manuscript. GLC contributed to the study design, performed experiments, analysed data and edited the manuscript. MLBJ, MBK, PRJ, HF performed experiments, analysed data and edited the manuscript. TM-P contributed to the study design, analysed data and edited the manuscript. All of the authors approved the final version of the manuscript. NB is responsible for the integrity of the work as a whole.

\section{References}

1. Bonner-Weir S, Weir GC (2005) New sources of pancreatic betacells. Nat Biotechnol 23:857-861

2. Inada A, Bonner-Weir S, Toschi E (2006) How can we get more beta cells? Curr Diab Rep 6:96-101

3. Nir T, Dor Y (2005) How to make pancreatic beta cells - prospects for cell therapy in diabetes. Curr Opin Biotechnol 16:524-529

4. Vasavada RC, Gonzalez-Pertusa JA, Fujinaka Y et al (2006) Growth factors and beta cell replication. Int J Biochem Cell Biol 38:931-950

5. El OA, Kawamori D, Dirice E et al (2013) Liver-derived systemic factors drive beta cell hyperplasia in insulin-resistant states. Cell Rep 3:401-410

6. Yi P, Park JS, Melton DA (2013) Betatrophin: a hormone that controls pancreatic \& beta; cell proliferation. Cell 153:747-758

7. Chung WS, Andersson O, Row R et al (2010) Suppression of Alk8-mediated Bmp signaling cell-autonomously induces pancreatic beta-cells in zebrafish. Proc Natl Acad Sci U S A 107:1142-1147

8. Krishnamurthy J, Ramsey MR, Ligon KL et al (2006) p16(INK4a) induces an age-dependent decline in islet regenerative potential. Nature 443:453-457 
9. Parsons JA, Brelje TC, Sorenson RL (1992) Adaptation of islets of Langerhans to pregnancy: increased islet cell proliferation and insulin secretion correlates with the onset of placental lactogen secretion. Endocrinology 130:1459-1466

10. Schulz TJ, Tseng YH (2009) Emerging role of bone morphogenetic proteins in adipogenesis and energy metabolism. Cytokine Growth Factor Rev 20:523-531

11. Wandzioch E, Zaret KS (2009) Dynamic signaling network for the specification of embryonic pancreas and liver progenitors. Science 324:1707-1710

12. Cozar-Castellano I, Fiaschi-Taesch N, Bigatel TA et al (2006) Molecular control of cell cycle progression in the pancreatic beta-cell. Endocr Rev 27:356-370

13. Van-Assche FA, Aerts L, De-Prins F (1978) A morphological study of the endocrine pancreas in human pregnancy. Br J Obstet Gynaecol 85:818-820

14. Saisho Y, Butler AE, Manesso E et al (2013) $\beta$-cell mass and turnover in humans: effects of obesity and aging. Diabetes Care 36: $111-117$

15. Massague J (2000) How cells read TGF-beta signals. Nature reviews. Mol Cell Biol 1:169-178

16. Boström KI, Jumabay M, Matveyenko A, Nicholas SB, Yao Y (2011) Activation of vascular bone morphogenetic protein signaling in diabetes mellitus. Circ Res 108:446-457

17. Koga M, Engberding N, Dikalova AE et al (2013) The bone morphogenic protein inhibitor, noggin, reduces glycemia and vascular inflammation in $\mathrm{db} / \mathrm{db}$ mice. Am J Physiol Heart Circ Physiol 305: H747-H755

18. Nett PC, Ortmann J, Celeiro J et al (2006) Transcriptional regulation of vascular bone morphogenetic protein by endothelin receptors in early autoimmune diabetes mellitus. Life Sci 78:2213-2218

19. San Martin A, Du P, Dikalova A et al (2007) Reactive oxygen species-selective regulation of aortic inflammatory gene expression in type 2 diabetes. Am J Physiol Heart Circ Physiol 292:H2073H2082

20. Dichmann DS, Miller CP, Jensen J et al (2003) Expression and misexpression of members of the FGF and TGFbeta families of growth factors in the developing mouse pancreas. Dev Dyn 226: 663-674

21. Goulley J, Dahl U, Baeza N et al (2007) BMP4-BMPR1A signaling in beta cells is required for and augments glucose-stimulated insulin secretion. Cell Metab 5:207-219

22. Zhang YQ, Zhang H, Maeshima A et al (2002) Up-regulation of the expression of activins in the pancreatic duct by reduction of the betacell mass. Endocrinology 143:3540-3547

23. Eizirik DL, Sammeth M, Bouckenooghe T et al (2012) The human pancreatic islet transcriptome: expression of candidate genes for type 1 diabetes and the impact of pro-inflammatory cytokines. PLoS Genet 8:e1002552

24. Moore F, Naamane N, Colli ML et al (2011) STAT1 is a master regulator of pancreatic beta-cell apoptosis and islet inflammation. J Biol Chem 286:929-941
25. Harmon EB, Apelqvist AA, Smart NG et al (2004) GDF11 modulates NGN3 + islet progenitor cell number and promotes beta-cell differentiation in pancreas development. Development 131:6163-6174

26. Hua H, Zhang YQ, Dabernat S et al (2006) BMP4 regulates pancreatic progenitor cell expansion through Id2. J Biol Chem 281:13574-13580

27. Rane SG, Lee JH, Lin HM (2006) Transforming growth factor-beta pathway: role in pancreas development and pancreatic disease. Cytokine Growth Factor Rev 17:107-119

28. Scott GJ, Ray MK, Ward T et al (2009) Abnormal glucose metabolism in heterozygous mutant mice for a type I receptor required for BMP signaling. Genesis 47:385-391

29. Akerfeldt MC, Laybutt DR (2011) Inhibition of Id1 augments insulin secretion and protects against high-fat diet-induced glucose intolerance. Diabetes 60:2506-2514

30. Brunstedt J (1980) Rapid isolation of functionally intact pancreatic islets from mice and rats by percollTM gradient centrifucation. Diabete Metab 6:87-89

31. Cucak H, Grunnet LG, Rosendahl A (2014) Accumulation of M1-like macrophages in type 2 diabetic islets is followed by a systemic shift in macrophage polarization. J Leukoc Biol 95:149-160

32. Parnaud G, Bosco D, Berney T et al (2008) Proliferation of sorted human and rat beta cells. Diabetologia 51:91-100

33. Frobøse H, Rønn SG, Heding PE et al (2006) Suppressor of cytokine signaling-3 inhibits interleukin-1 signaling by targeting the TRAF-6/TAK1 complex. Mol Endocrinol 20:1587-1596

34. Poulsen F, Jensen KB (2007) A luminescent oxygen channeling immunoassay for the determination of insulin in human plasma. J Biomol Screen 12:240-247

35. Miyazono K, Miyazawa K (2002) Id: a target of BMP signaling. Sci STKE:e40

36. Brun T, Franklin I, StOnge L et al (2004) The diabetes-linked transcription factor PAX4 promotes beta-cell proliferation and survival in rat and human islets. J Cell Biol 167:1123-1135

37. Kim SK, MacDonald RJ (2002) Signaling and transcriptional control of pancreatic organogenesis. Curr Opin Genet Dev 12:540-547

38. Brown ML, Kimura F, Bonomi LM et al (2011) Differential synthesis and action of TGF-superfamily ligands in mouse and rat islets. Islets 3:367-375

39. Lasorella A, Uo T, Iavarone A (2001) Id proteins at the cross-road of development and cancer. Oncogene 20:8326-8333

40. Gu C, Stein GH, Pan N et al (2010) Pancreatic beta cells require NeuroD to achieve and maintain functional maturity. Cell Metab 11: 298-310

41. Hussein KA, Choksi K, Akeel S et al (2014) Bone morphogenetic protein 2: a potential new player in the pathogenesis of diabetic retinopathy. Exp Eye Res 125:79-88

42. Tominaga $\mathrm{T}$, Abe $\mathrm{H}$, Ueda $\mathrm{O}$ et al (2011) Activation of bone morphogenetic protein 4 signaling leads to glomerulosclerosis that mimics diabetic nephropathy. J Biol Chem 286:20109-20116

43. Derwall M, Malhotra R, Lai CS et al (2012) Inhibition of bone morphogenetic protein signaling reduces vascular calcification and atherosclerosis. Arterioscler Thromb Vasc Biol 32:613-622 